DOI:10.17951/h.2015.49.4.695

\begin{tabular}{lcl}
\hline \multicolumn{3}{c}{ A N N A L E S } \\
UNIVERSITATIS & MARIAE CURIE-SKŁODOWSKA \\
LUBLIN - POLONIA \\
VOL. XLIX, 4 & SECTIOH \\
\hline
\end{tabular}

Uniwersytet Marii Curie-Skłodowskiej, Wydział Ekonomiczny

\title{
ELŻBIETA WROŃSKA-BUKALSKA
}

elzbieta.bukalska@umcs.lublin.pl

\section{Jednoczesne obniżenie i podwyższenie kapitału zakładowego - przyczyny i skutki}

Simultaneous Decrease and Increase of the Share Capital - Reasons and Results

\begin{abstract}
Słowa kluczowe: funkcje kapitału zakładowego, podwyższenie kapitału zakładowego, obniżenie kapitału zakładowego
\end{abstract}

Keywords: share capital functions, raising capital, decrease in share capital

Kod JEL: G32, M21, M41

\section{Wstęp}

Kapitał zakładowy jest elementem kapitałów własnych przedsiębiorstwa. Odgrywa on istotną rolę w finansowaniu majątku oraz wypełnia szereg innych funkcji mających znaczenie zarówno dla samego przedsiębiorstwa, jak i dla współpracujących z nim podmiotów oraz właścicieli. W literaturze przedmiotu powszechnie przyjmuje się, że kapitał zakładowy powinien być podwyższany w sytuacji intensywnego wzrostu przedsiębiorstwa, natomiast obniżany w sytuacji, gdy przedsiębiorstwo ogranicza swój zakres działania i majątku. Zaobserwowane przypadki jednoczesnego obniżenia i podwyższenia kapitału zakładowego nie mieszczą się jednak w tak ujętych potrzebach zmiany poziomu kapitału zakładowego. Jednoczesne obniżenie i podwyższenie kapitału wydaje się być nieuzasadnione z ekonomicznego punktu widzenia, szczególnie gdy kapitał jest obniżany i podwyższany o taką samą kwotę, a dodatkowo należy ponieść koszty przeprowadzenia procedury obniżenia i podwyższenia kapitału. 
Celem opracowania jest identyfikacja przyczyn oraz skutków jednoczesnego zastosowania obniżenia i podwyższenia kapitału zakładowego. Dla tak określonego celu została sformułowana hipoteza badawcza stwierdzająca, że jednoczesne obniżenie i podwyższenie kapitału zakładowego jest narzędziem realizowanych przez podmioty gospodarcze działań innych niż związane ze zwiększaniem czy zmniejszaniem zakresu działania. Dla potrzeb weryfikacji postawionej hipotezy zastosowano metodę analizy przypadków w latach 2010-2014. W okresie tym zidentyfikowano 20 przypadków jednoczesnego podwyższenia i obniżenia kapitału zakładowego.

\section{Istota i funkcje kapitału zakładowego}

Wniesienie i posiadanie kapitału zakładowego jest warunkiem zawiązania i funkcjonowania spółki kapitałowej (spółki z ograniczoną odpowiedzialnością oraz spółki akcyjnej). W praktyce funkcjonowania spółek kapitałowych, gdzie wniesienie kapitału jest jednym z podstawowych obowiązków właściciela (udziałowca, akcjonariusza), wymagane jest utrzymanie minimalnego jego poziomu (5000 zł w spółce z ograniczoną odpowiedzialnością lub 100000 zł w spółce akcyjnej) [Ustawa..., 2000]. Zgromadzenie kapitału i jego utrzymanie w spółkach kapitałowych stanowi kluczowy element spółki i jest ważniejsze niż zachowanie składu osobowego wspólników.

Kapitał zakładowy ma zasadnicze znaczenie dla funkcjonowania i rozwoju przedsiębiorstwa, gdyż jest najbardziej stabilną podstawą jego funkcjonowania [Grzywacz, 2008, s. 14]. Stabilność ta wyraża się tym, że kapitał ten jest wnoszony na czas nieokreślony. Na zwrot kapitałów właściciele mogą liczyć dopiero po zakończeniu działalności przez przedsiębiorstwo. Znaczenie kapitału zakładowego wynika więc przede wszystkim z funkcji, jakie pełni on w działalności gospodarczej.

Jedna z klasyfikacji pozwala wyodrębnić funkcję [Ickiewicz, 2011, s. 43; Duliniec, 2011, s. 80] gwarancyjną oraz roboczą. Funkcja gwarancyjna polega na tym, że kapitał zakładowy stanowi zabezpieczenie dla wierzycieli, stanowi źródło zdolności kredytowej jednostki (im jest większy, tym ryzyko wierzycieli mniejsze), a funkcja robocza polega na tym, że kapitał własny stanowi podstawowe źródło finansowania majątku i działalności.

Inne ujęcie wyodrębnia funkcję prawną, gospodarczą i gwarancyjną kapitału zakładowego [Skawiańczyk, 2009, s. 58; Kosiorkiewicz, 1999, s. 26-38; Ostaszewski, Cicirko, 2005, s. 93; Woźniak-Sobczak, 2005, s. 2-35]. Funkcja prawna polega na tym, że stanowi on zasadniczy warunek uczestnictwa w spółce. W spółce kapitałowej kapitał wiedzie prymat nad osobami, to kapitał i jego struktura determinują pozycję wspólników w spółce. Posiadany udział jest podstawą praw zarówno majątkowych, jak i korporacyjnych w spółce. Funkcja gospodarcza przejawia się tym, że kapitał stanowi zespół środków umożliwiający spółce podjęcie i prowadzenie działalności gospodarczej (z jednej strony zapis księgowy po stronie pasywów, 
któremu po stronie aktywów odpowiadają składniki majątkowe). Funkcja gwarancyjna natomiast jest związana $\mathrm{z}$ ograniczeniem odpowiedzialności wspólników za długi spółki. Skoro wspólnicy zasadniczo nie ponoszą odpowiedzialności za zobowiązania spółki, to właśnie kapitał zakładowy powinien chronić interesy wierzycieli.

Najszersze ujęcie pozwala wyodrębnić następujące funkcje kapitału własnego [Chojnacka, 2012, s. 28; Waśniewski, 1997, s. 292]: funkcja założycielska (powstanie przedsiębiorstwa jest uzależnione od wniesienia wkładu kapitałowego), funkcja finansowa (kapitał jest traktowany jako źródło finansowania majątku spółki), funkcja gwarancyjna (kapitał własny stanowi zabezpieczenie dla wierzycieli, funkcja ta jest istotna w przypadku spółek kapitałowych posiadających odrębną od właścicieli osobowość prawną), funkcja wyrównawcza (posiadane przez przedsiębiorstwo rezerwy kapitałowe pozwalają na pokrycie bieżących strat i wypłatę dywidendy), funkcja pomiarowa (wielkość kapitału własnego jest podstawą do podziału dywidendy), funkcja reprezentacyjna (poziom i struktura kapitału własnego świadczą o sytuacji finansowej przedsiębiorstwa i jego pozycji, co tworzy i podtrzymuje kredyt zaufania dla przedsiębiorstwa) oraz funkcja inicjatywna dla kierownictwa przedsiębiorstwa (dzięki kapitałowi własnemu przedsiębiorstwo zachowuje swoją suwerenność i niezależność w stosunku do otoczenia, co umożliwia kierowanie i realizowanie przedsięwzięć).

\section{Metody i skutki podwyższenia i obniżenia kapitału zakładowego}

\subsection{Podwyższenie kapitału zakładowego}

Kodeks spółek handlowych przewiduje dwa sposoby podwyższenia kapitału zakładowego [Ustawa..., 2000]: 1) przez zwiększenie wartości nominalnej istniejących akcji/udziałów lub 2) przez ustanowienie nowych akcji/udziałów. Ponadto podwyższenie kapitału może nastąpić w przypadku połączenia dwóch podmiotów.

Podwyższenie kapitału zakładowego (bez względu na sposób) może być opłacone [Sajnóg, 2013]: 1) przesunięciem części kapitału zapasowego na kapitał zakładowy lub 2) wpłatami (gotówka lub aport) dokonanymi przez właścicieli.

Prawo (ale nie obowiązek) pierwszeństwa do objęcia nowych udziałów mają dotychczasowi wspólnicy (w stosunku do swoich udziałów). W sytuacji wyłączenia prawa poboru pojawiają się nowi akcjonariusze, co powoduje zmniejszenie znaczenia i udziału w głosach dotychczasowych akcjonariuszy. Dla spółki jednak pojawia się szansa zebrania zaplanowanej kwoty z uwagi na poszerzenie zakresu osób mogących uczestniczyć w finansowaniu spółki. Tab. 1 prezentuje skutki zastosowania różnych sposobów podwyższenia i opłacenia podwyższenia kapitału zakładowego z punktu widzenia spółki oraz właścicieli. 
Tab. 1. Skutki zastosowania różnych sposobów podwyższenia i opłacenia podwyższenia kapitału zakładowego z punktu widzenia spółki oraz właścicieli

\begin{tabular}{|c|c|c|}
\hline & Skutki dla spółki & Skutki dla właściciela \\
\hline $\begin{array}{l}\text { Zwiększenie } \\
\text { wartości nominalnej } \\
\text { akcji/udziału } \\
\text { i opłacenie środkami } \\
\text { spółki (przesunięcie } \\
\text { części kapitału } \\
\text { zapasowego) }\end{array}$ & $\begin{array}{l}\text { Wartość majątku i kapitałów własnych nie } \\
\text { ulega zmianie; zmianie ulega wyłącznie } \\
\text { wewnętrzna struktura kapitału własnego - } \\
\text { zwięeksza się wartość kapitału zakładowe- } \\
\text { go, a zmniejszeniu ulega wartość kapitału } \\
\text { zapasowego }\end{array}$ & $\begin{array}{l}\text { Sytuacja ulega znaczącej poprawie, gdyż } \\
\text { zwiększa się wartość nominalna posiada- } \\
\text { nego zasobu akcji bez konieczności wydat- } \\
\text { kowania jakichkolwiek środków ze strony } \\
\text { właściciela }\end{array}$ \\
\hline \begin{tabular}{|l|} 
Zwiększenie \\
wartości nominalnej \\
akcji/udziału \\
i opłacenie środkami \\
właścicieli \\
\end{tabular} & $\begin{array}{l}\text { Zwiększeniu ulega zasób majątkowy spółki } \\
\text { w związku z wpłatami dokonanymi przez } \\
\text { właścicieli (gotówka, aport), jednocześnie } \\
\text { zwiększa się wartość kapitału zakładowego } \\
\text { i kapitałów własnych }\end{array}$ & $\begin{array}{l}\text { Sytuacja jest neutralna, bowiem następuje } \\
\text { zwiększenie wartości nominalnej pakietu } \\
\text { akcji, ale wiąże się to z koniecznością do- } \\
\text { konania zapłaty }\end{array}$ \\
\hline $\begin{array}{l}\text { Wyemitowanie } \\
\text { nowych udziałów/ } \\
\text { akcji i opłacenie } \\
\text { środkami spółki }\end{array}$ & $\begin{array}{l}\text { Wartość majątku i kapitałów własnych nie } \\
\text { ulega zmianie; zmianie ulega wyłącznie } \\
\text { wewnętrzna struktura kapitału własnego - } \\
\text { zwiększa się wartość kapitału zakładowe- } \\
\text { go, a zmniejszeniu ulega wartość kapitału } \\
\text { zapasowego. }\end{array}$ & $\begin{array}{l}\text { Sytuacja ulega znaczącej poprawie, gdyż } \\
\text { zwiększa się wartość nominalna posiada- } \\
\text { nego zasobu akcji bez konieczności wydat- } \\
\text { kowania jakichkolwiek środków ze strony } \\
\text { właściciela }\end{array}$ \\
\hline $\begin{array}{l}\text { Wyemitowanie } \\
\text { nowych udziałów/ } \\
\text { akcji i opłacenie } \\
\text { środkami właścicieli }\end{array}$ & $\begin{array}{l}\text { Zwiększeniu ulega zasób majątkowy spółki } \\
\text { w związku z wpłatami dokonanymi przez } \\
\text { właścicieli (gotówka, aport), jednocześnie } \\
\text { zwiększa się wartość kapitału zakładowego } \\
\text { i kapitałów własnych }\end{array}$ & $\begin{array}{l}\text { W przypadku skorzystania z prawa poboru } \\
\text { sytuacja jest neutralna, bowiem następuje } \\
\text { zwiększenie wartości nominalnej pakietu } \\
\text { akcji, ale wiąże się to z koniecznością do- } \\
\text { konania zapłaty } \\
\text { W przypadku nieskorzystania z prawa po- } \\
\text { boru przez dotychczasowych akcjonariu- } \\
\text { szy wartość nominalna posiadanego przez } \\
\text { nich zasobu akcji nie ulega zmianie, ale } \\
\text { pojawiają się nowi akcjonariusze, co po- } \\
\text { woduje zmniejszenie znaczenia i udziału } \\
\text { w głosach dotychczasowych akcjonariuszy }\end{array}$ \\
\hline
\end{tabular}

Źródło: opracowanie własne.

Podwyższenie kapitału jest więc możliwe przy zastosowaniu różnych metod oraz sposobu opłacenia, co generuje zróżnicowane skutki zarówno dla spółki, jak i jej właścicieli.

\subsection{Obniżenie kapitału zakładowego}

W celu obniżenia kapitału zakładowego Kodeks spółek handlowych przewiduje dwa podstawowe sposoby, pod warunkiem zachowania jego minimalnego poziomu [Ustawa..., 2000]: 1) przez zmniejszenie wartości nominalnej akcji lub 2) w drodze umorzenia akcji. Dodatkowo obniżenie kapitału może nastąpić w przypadku podziału spółki (tzw. podział przez wydzielenie).

Obniżenie kapitału zakładowego w drodze umorzenia części akcji jest przeprowadzane w dwóch etapach. Spółka w pierwszej kolejności dokonuje ich nabycia. 
Zakup akcji własnych oznacza wypływ gotówki w kwocie odzwierciedlającej iloczyn ceny nabycia oraz ilości nabytych akcji. Zakupione akcje są prezentowane jako element kapitałów własnych (ujemna wartość w pozycji „,należne wpłaty na kapitał zakładowy") odzwierciedlający iloczyn wartości nominalnej akcji oraz ilość nabytych akcji. W przypadku gdy cena zapłaty przekraczała wartość nominalną, różnica między ceną a wartością nominalną pomniejsza kapitał zapasowy. Pozostałą część różnicy, przewyższającą kapitał zapasowy, wykazuje się jako stratę z lat ubiegłych. W przypadku gdy cena zapłacona za nabycie umarzanych akcji jest niższa niż wartość nominalna, różnica ta zwiększa kapitał zapasowy. W następnej kolejności umarzane są zakupione akcje ze skutkiem obniżenia kapitału zakładowego (i następuje przeksięgowanie z konta „należne wpłaty na kapitał zakładowy” na konto „kapitał zakładowy") ${ }^{1}$. Tab. 2 prezentuje skutki zastosowania różnych sposobów obniżenia kapitału zakładowego z punktu widzenia spółki oraz właścicieli.

Tab. 2. Skutki zastosowania różnych sposobów obniżenia kapitału zakładowego z punktu widzenia spółki oraz właścicieli

\begin{tabular}{|c|c|c|}
\hline & Skutki dla spółki & Skutki dla wlaściciela \\
\hline $\begin{array}{l}\text { Zmniejszenie } \\
\text { wartości } \\
\text { nominalnej }\end{array}$ & $\begin{array}{l}\text { Kwota uzyskana z obniżenia kapitału zakładowego w dro- } \\
\text { dze zmniejszenia wartości nominalnej akcji zostaje przek- } \\
\text { sięgowana na kapitał zapasowy. W tym przypadku zasób } \\
\text { majątkowy (gotówki czy rzeczowych aktywów) nie ulega } \\
\text { zmianie; nie ulega zmianie wartość źródeł finansowa- } \\
\text { nia (pasywów), jak również wartość kapitału własnego. } \\
\text { Zmniejszeniu ulega wartość kapitału zakładowego, a war- } \\
\text { tość kapitału zapasowego ulega zwiększeniu. A zatem ule- } \\
\text { ga zmianie wewnętrzna struktura kapitału własnego }\end{array}$ & $\begin{array}{l}\text { Sytuacja właścicieli ulega zna- } \\
\text { czącemu pogorszeniu. W przy- } \\
\text { padku zmniejszenia wartości } \\
\text { nominalnej ilość akcji w rę- } \\
\text { kach akcjonariuszy pozostaje } \\
\text { niezmieniona, ale wartość no- } \\
\text { minalna posiadanego zasobu } \\
\text { akcji ulega zmniejszeniu }\end{array}$ \\
\hline $\begin{array}{l}\text { Umorzenie } \\
\text { udziałów/akcji }\end{array}$ & $\begin{array}{l}\text { Zmniejszeniu ulega zasób majątkowy spółki (gotówka } \\
\text { lub rzeczowe aktywa w zależności od formy płatności za } \\
\text { nabyte przez spółkę akcje), zmniejszeniu ulega również } \\
\text { wartość kapitałów własnych i kapitału zakładowego }\end{array}$ & $\begin{array}{l}\text { Zmniejszenie wartości pakietu } \\
\text { akcji będącego w ich posiada- } \\
\text { niu, ale w zamian otrzymują } \\
\text { wynagrodzenie }\end{array}$ \\
\hline
\end{tabular}

Źródło: opracowanie własne.

Z formalnego punktu widzenia procedura jednoczesnego obniżenia i podwyższenia kapitału może przyjmować następujące podstawowe kombinacje: a) umorzenie akcji oraz nowa emisja akcji, b) obniżenie wartości nominalnej akcji oraz nowa emisja akcji, c) umorzenie akcji oraz podwyższenie wartości nominalnej akcji, d) obniżenie wartości akcji oraz podwyższenie wartości akcji. Zastosowanie jednej z wyżej wskazanych procedur generuje jednak zróżnicowane skutki dla spółki oraz jej właścicieli. Ważne jest też zidentyfikowanie przyczyn stosowania jednoczesnego obniżenia i podwyższenia kapitału zakładowego. W tym celu zastosowano metodę analizy przypadku.

1 Możliwe jest też umorzenie akcji bez obniżania kapitału zakładowego, nie jest to jednak przedmiotem rozważań niniejszego opracowania. 


\section{Analiza przypadków spólek dokonujących jednoczesnego obniżenia i podwyższenia kapitału}

Analizą objęto przypadki jednoczesnego obniżenia i podwyższenia kapitału zakładowego w okresie 2010-2014. Dotyczy ona spółek giełdowych zarówno z rynku głównego GPW, jak i NewConnect (łącznie 15 podmiotów) oraz spółek niepublicznych (pięć podmiotów). Łącznie analizą objęto 20 podmiotów. Do próby zakwalifikowano wszystkie podmioty, które w analizowanym okresie podjęły decyzje o jednoczesnym obniżeniu i podwyższeniu kapitału zakładowego. Tab. 3 prezentuje dane ilościowe charakteryzujące analizowane przypadki jednoczesnego obniżenia i podwyższenia kapitału.

Tab. 3. Zmiany wartości kapitału zakładowego w analizowanych podmiotach (dane w tys. zł)

\begin{tabular}{|c|c|c|c|c|c|}
\hline Wyszczególnienie & $\begin{array}{c}\text { Kwota } \\
\text { wyjściowa } \\
\text { kapitału } \\
\text { zakladowego }\end{array}$ & $\begin{array}{c}\text { Kwota } \\
\text { obniżenia } \\
\text { kapitału }\end{array}$ & $\begin{array}{c}\text { \% zmiana } \\
\text { kapitału } \\
\text { zakładowego }\end{array}$ & $\begin{array}{c}\text { Kwota } \\
\text { podwyższenia } \\
\text { kapitału }\end{array}$ & $\begin{array}{c}\text { \% zmiana } \\
\text { kapitału } \\
\text { zakladowego }\end{array}$ \\
\hline \multicolumn{6}{|c|}{ Metoda: umorzenie akcji oraz nowa emisja akcji } \\
\hline Spółka X* & 100,0 & 20,0 & $20 \%$ & 20,0 & $20 \%$ \\
\hline SMT S.A. & 1130,8 & 31,7 & $2,8 \%$ & 31,7 & $2,8 \%$ \\
\hline Ekogeneracja Sp. z o.o. & 500,0 & 350,0 & $70 \%$ & 350,0 & $70 \%$ \\
\hline Polkomtel Sp. z o.o. & 2050000,0 & 2050000,0 & $100 \%$ & 3510300,0 & $171,2 \%$ \\
\hline Spółka Y* & 210050,0 & 180000,0 & $86 \%$ & 180000,0 & $86 \%$ \\
\hline ZWiK Sp. z o.o. & 89250,0 & 3356,4 & $3,8 \%$ & 7537,8 & $8,4 \%$ \\
\hline Presco Investment S.A. & 100000,0 & 31500,0 & $31,5 \%$ & 700,0 & $0,7 \%$ \\
\hline IPO S.A. & 1863,5 & 952,5 & $51 \%$ & 952,5 & $51 \%$ \\
\hline \multicolumn{6}{|c|}{ Metoda: obniżenie wartości nominalnej akcji oraz nowa emisja akcji } \\
\hline Drewex S.A. & 9525,0 & 3524,2 & $37 \%$ & 3524,3 & $37 \%$ \\
\hline Skystone Capital S.A. & 14685,1 & 14538,2 & $99 \%$ & 17000,0 & $115,8 \%$ \\
\hline PKS Olsztyn Sp. z o.o. & 5000,0 & 3500,0 & $70 \%$ & 1000,0 & $20 \%$ \\
\hline Trion S.A. & 34003,9 & 24813,7 & $73 \%$ & 24813,7 & $73 \%$ \\
\hline Mostostal Export S.A. & 44558,8 & 22279,4 & $50 \%$ & 22279,4 & $50 \%$ \\
\hline Devora S.A. & 9377,0 & 9142,6 & $97,5 \%$ & 6798,3 & $72,5 \%$ \\
\hline JHM Development S.A. & 125000,0 & 62500,0 & $50 \%$ & 110500,0 & $88,4 \%$ \\
\hline $\begin{array}{l}\text { Index Copernicus Inter- } \\
\text { national S.A. }\end{array}$ & 7775,8 & 3887,9 & $50 \%$ & 3887,9 & $50 \%$ \\
\hline BNP Paribas S.A. & 1304380,4 & 300128,0 & $23 \%$ & 300128,0 & $23 \%$ \\
\hline Art New Media S.A. & 10008,5 & 9007,7 & $90 \%$ & 300,0 & $3 \%$ \\
\hline GPPI S.A. & 3937,9 & 2310,0 & $59 \%$ & 3937,9 & $100 \%$ \\
\hline FON Ecology S.A. & 2900,0 & 2800,0 & $96 \%$ & 10800,0 & $372,4 \%$ \\
\hline
\end{tabular}

* spółka nie wyraziła zgody na wykorzystanie jej nazwy

Źródło: opracowanie własne na podstawie analizy raportów bieżących.

Analizując dane ilościowe, warto zauważyć, że w 14 przypadkach dokonano istotnego obniżenia kapitału zakładowego o $50 \%$ i więcej w stosunku do poziomu wyjściowego. W 10 przypadkach na 20 analizowanych podmiotów kwota podwyższenia była równa kwocie obniżenia, w sześciu przypadkach kwota obniżenia była 
niższa niż kwota podwyższenia, a w czterech przypadkach kwota podwyższenia była niższa niż kwota obniżenia.

Analizując przyczyny jednoczesnego obniżenia i podwyższenia kapitału zakładowego wyodrębnić można szereg interesujących przypadków.

Spółka X (2011) - konflikt między współwłaścicielami doprowadził do umorzenia akcji tego akcjonariusza, który dąży do wyjścia ze spółki; wychodzący współwłaściciel nie chciał odsprzedać swoich udziałów któremukolwiek innemu pozostającemu w spółce; podwyższenie kapitału umożliwiło wprowadzenie nowego wspólnika w miejsce ustępującego i uzupełnienie kapitału zakładowego.

SMT S.A. (2013) - umarzane akcje były objęte lock-up'em i uniemożliwiały ich zbycie przez właściciela na rzecz podmiotu trzeciego; akcje nowej emisji (bez lock-up'u) zostały objęte przez tego samego właściciela, któremu akcje umorzono, jednak z możliwością ich zbycia na rzecz podmiotu trzeciego i osiągnięcia przez niego $z$ tej transakcji dochodu.

Ekogeneracja Sp. z o.o. (2014) - nastąpiło umorzenie części udziałów dotychczasowego właściciela (spółki matki), podwyższenie kapitału w drodze utworzenia nowych udziałów i objęcie ich przez osobę fizyczną, która opłaciła udziały aportem (licencja) i uzyskała dominujący udział w kapitale zakładowym.

Polkomtel Sp. z o.o. (2012) - nastąpiło połączenia ze Spartan Capital Holdings (Spartan). Spartan była jedynym wspólnikiem Polkomtela. Połączenie nastąpiło przez przeniesienie całego majątku Spartana (w tym także udziałów będących w posiadaniu Spartan Capital Holding) na Polkomtel. Polkomtel w związku z tym stał się właścicielem swoich własnych udziałów. Dokonano więc umorzenia bez wynagrodzenia udziałów własnych Polkomtela, nabytych przez Polkomtel na skutek połączenia, i obniżono kapitał zakładowy Polkomtela. Kwota z umorzenia udziałów zasiliła kapitał zapasowy Polkomtela. Jednocześnie podwyższono kapitał zakładowy Polkomtela przez utworzenie nowych udziałów opłaconych z utworzonego wcześniej kapitału zapasowego. Wszystkie udziały w podwyższonym kapitale zakładowym Polkomtela zostały wydane wspólnikom Spartana, którzy teraz stali się wspólnikami Polkomtela.

Spółka Y (2013) - w wyniku połączenia ze spółką dominującą dokonała umorzenia udziałów bez wynagrodzenia, obniżenia kapitału zakładowego na rzecz zwiększenia kapitału zapasowego (wartość udziałów znajdująca się w posiadaniu przejętej spółki dominującej) i jednoczesnego podwyższenia kapitału zakładowego przez przeniesienie z kapitału zapasowego takiej samej kwoty w celu utworzenia nowych udziałów i ich rozdysponowania między właścicieli spółki dominującej.

Zakład Wodociągów i Kanalizacji Sp. z o.o. w Świnoujściu (2010) - w ramach wynagrodzenia za umorzone udziały ZWiK przeniósł na właściciela (gminę Miasta Świnoujście) własność urządzeń. Jednocześnie emisja nowych udziałów została objęta przez gminę. Udziały zostaną pokryte wkładami niepieniężnymi w postaci obiektów infrastruktury technicznej (odmiennej od tej przejętej przez gminę w związku z umorzeniem udziałów i obniżeniem kapitału). 
Presco Investments S.à r.l. (2013) - nastąpiło obniżenie kapitału zakładowego przez umorzenie udziałów klasy A (przeznaczonych na finansowanie inwestycji na rynku czeskim) należących do spółki matki z jednoczesnym podwyższeniem kapitału zakładowego przez utworzenie udziałów klasy B (przeznaczonych na finansowanie inwestycji na rynku wschodnim) i objęciem ich przez spółkę matkę. Źródłem finansowania nowo objętych udziałów były środki pozyskane przez spółkę matkę z obniżenia kapitału zakładowego podmiotu zależnego.

IPO S.A. (2014) - w wyniku formalnego błędu w przebiegu oferty akcji serii D akcje te nie zostały prawidłowo zarejestrowane przez Krajowy Depozyt Papierów Wartościowych, a także nie zostały prawidłowo zapisane na rachunkach maklerskich akcjonariuszy, którzy objęli te akcje. W tej sytuacji jedynym wyjściem stało się umorzenie akcji serii $\mathrm{D}$, obniżenie kapitału zakładowego oraz podwyższenie kapitału zakładowego przez emisję akcji serii E i wydanie nowych akcji akcjonariuszom spółki (uczestniczącym w emisji akcji serii D).

Spółki: Drewex (2011), Skystone Capital (2014), PKS w Olsztynie (2012), Trion (2010), Mostostal Export (2013), Devora (2013) - środki pochodzące z obniżenia wartości nominalnej akcji i kapitału zakładowego zostały przeksięgowane na kapitał zapasowy i stały się podstawą rozliczenia strat wykazanych przez te podmioty w sprawozdaniach finansowych. Środki pochodzące z obniżenia kapitału zakładowego w wyniku obniżenia wartości nominalnej nie zostały wypłacone właścicielom, co stanowi swego rodzaju partycypację właścicieli w osiągniętych przez spółkę stratach. Emisja nowych akcji ma na celu pozyskanie środków na finansowanie bieżącego funkcjonowania, rozwoju spółki, przeprowadzenia procesu restrukturyzacji. Emisja nowych akcji najczęściej odbywała się z wyłączeniem prawa poboru, a więc była podyktowana potrzebą pozyskania nowych akcjonariuszy (czy też niechęcią dotychczasowych do angażowania kolejnych środków w spółkę, która wypracowała straty). Nowa emisja akcji dokonywała się również po cenie emisyjnej równej nowej obniżonej wartości nominalnej. Zmniejszenie wartości nominalnej akcji dało szansę powodzenia procesu podwyższenia kapitału i pozyskania nowych środków. Wszystkie spółki podkreślały potrzebę opłacenia nowo wyemitowanych akcji gotówką.

Spółki: Devora (2013), Mostostal Export (2013), JHM Development (2013), Index Copernicus International (2011), BNP Paribas Bank Polska (2013), Trion (2010), Art. New Media (2013), GPPI (2014), Fon Ecology (2011) - notowania kursów akcji kształtowały się poniżej ich wartości nominalnej, co nie było korzystne dla wizerunku spółek. Obniżenie wartości nominalnej akcji umożliwiło spółkom pozyskanie nowych środków przez emisje nowych akcji o niższej wartości nominalnej (i emisyjnej, najczęściej równej wartości nominalnej). Miało to zapewnić powodzenie emisji. Emisja nowych akcji po cenie niższej niż wartość nominalna nie jest bowiem dopuszczalna. Emisje najczęściej odbywały się z wyłączeniem prawa poboru, a więc potrzebą pozyskania nowych akcjonariuszy (czy też niechęcią dotychczasowych do angażowania kolejnych środków w spółkę, która przejęła część środków właścicieli na własne potrzeby). Wszystkie spółki zwracały uwagę, że pokrycie obejmowanych 
akcji powinno nastąpić w całości wkładem pieniężnym. Warto zwrócić uwagę, że w tej grupie znajduje się kilka spółek (Trion, Mostostal Export, Devora), które obniżyły kapitał zakładowy również z powodu wygenerowanej straty. Oznacza to, że w kursach nastąpiło odzwierciedlenie trudnej sytuacji finansowej podmiotu.

\section{Przyczyny, przebieg i skutki jednoczesnego obniżenia i podwyższenia kapitału}

Analizując wszystkie przypadki jednoczesnego obniżenia i podwyższenia kapitału, można w sposób syntetyczny wyodrębnić przyczyny i zastosowane procedury oraz skutki tego rodzaju działań. Tab. 4 prezentuje zestawienie wyników analizy przyczyn, metod oraz skutków.

W analizowanej grupie spółek nie było żadnej, która dokonałaby umorzenia części akcji oraz podwyższenia wartości nominalnej akcji pozostałych. Taką sytuację można jednak sobie wyobrazić w przypadku, gdyby właściciele chcieli pozbyć się wspólnika, z którym są skonfliktowani, a następnie podwyższyli kapitał do sytuacji wyjściowej przez dokonanie podwyższenia wartości nominalnej akcji, przeniesienie kapitału zapasowego (nagroda dla pozostających lojalnych wspólników) lub dopłaty gotówkowe.

W analizowanej grupie nie było też spółek, które dokonałyby obniżenia wartości akcji oraz podwyższenia wartości akcji. Sytuacja taka wydaje się być wykluczająca się, jeśli obniżenie skutkowałoby przeniesieniem kwot na kapitał zapasowy, a podwyższenie wartości nominalnej nastąpiłoby przez przeniesienie kwot z kapitału zapasowego, chyba że podwyższenie wartości akcji następowałoby w drodze wpłat gotówkowych dotychczasowych wspólników. Trudno jednak sobie wyobrazić, że właściciel, którego część bogactwa przejęła spółka, będzie gotowy angażować dodatkowe własne środki na dalsze wspieranie jej działalności. Tab. 4 zawiera zestawienie przyczyn, metod oraz skutków jednoczesnego obniżenia i podwyższenia kapitału zakładowego w analizowanej grupie podmiotów.

Tab. 4. Zestawienie przyczyn, metod oraz skutków jednoczesnego obniżenia i podwyższenia kapitału zakładowego

\begin{tabular}{|l|l|l|l|l|}
\hline \multicolumn{1}{|c|}{ Przyczyna } & \multicolumn{1}{|c|}{ Spólki } & \multicolumn{1}{c|}{ Procedura } & \multicolumn{1}{c|}{ Skutki dla spółki } & \multicolumn{1}{c|}{ Skutki dla właścicieli } \\
\hline $\begin{array}{l}\text { Dążenie do } \\
\text { zmiany struktury } \\
\text { własnościowej }\end{array}$ & $\begin{array}{l}\text { Spółka X, SMT, } \\
\text { Ekogeneracja, } \\
\text { Dystrybucja, } \\
\text { Polkomtel, } \\
\text { spółka Y }\end{array}$ & $\begin{array}{l}\text { Umorzenie akcji } \\
\text { i nowa emisja } \\
\text { akcji }\end{array}$ & $\begin{array}{l}\text { Neutralne: wprawdzie } \\
\text { skup akcji został opłacony } \\
\text { środkami spółki, ale do- } \\
\text { datkowe środki pieniężne } \\
\text { wpłynęły w związku } \\
\text { z nową emisją akcji }\end{array}$ & $\begin{array}{l}\text { Neutralne: w zamian } \\
\text { za odsprzedane akcje } \\
\text { otrzymuje zapłatę, nastę- } \\
\text { puje jednak zmniejsze- } \\
\text { nie udziału w kapitale } \\
\text { i głosach }\end{array}$ \\
\hline $\begin{array}{l}\text { Realizowanie } \\
\text { przez spółkę } \\
\text { dominującą poli- } \\
\text { tyki rozdyspono- } \\
\text { wania zasobów }\end{array}$ & $\begin{array}{l}\text { ZWiK, } \\
\text { mesco Invest- }\end{array}$ & $\begin{array}{l}\text { Umorzenie akcji } \\
\text { i nowa emisja } \\
\text { mejoji }\end{array}$ & $\begin{array}{l}\text { Neutralne: wprawdzie } \\
\text { skup akcji został opłacony } \\
\text { środkami spółki, ale do- } \\
\text { datkowe środki wpłynęły } \\
\text { w związku z nową emisją } \\
\text { akcji }\end{array}$ & $\begin{array}{l}\text { Korzystne: za umorzone } \\
\text { akcje otrzymuje zapłatę, } \\
\text { ale emisja nowych akcji } \\
\text { wymaga ich opłacenia; } \\
\text { jednak zgodnie z prefe- } \\
\text { rencjami właścicieli }\end{array}$ \\
\hline
\end{tabular}




\begin{tabular}{|c|c|c|c|c|}
\hline $\begin{array}{l}\text { Korekta kapitału } \\
\text { zakładowego } \\
\text { o straty z lat } \\
\text { ubiegłych oraz } \\
\text { pozyskania } \\
\text { kapitału na } \\
\text { finansowanie } \\
\text { działalności }\end{array}$ & $\begin{array}{l}\text { Drewex, } \\
\text { Skystone } \\
\text { Capital, } \\
\text { PKS } \\
\text { w Olsztynie, } \\
\text { Trion, } \\
\text { Mostostal } \\
\text { Export, Devora }\end{array}$ & $\begin{array}{l}\text { Obniżenie war- } \\
\text { tości nominalnej } \\
\text { akcji i emisja } \\
\text { nowych akcji }\end{array}$ & $\begin{array}{l}\text { Korzystne: część kapitału } \\
\text { zakładowego została } \\
\text { przeksięgowana na kapitał } \\
\text { zapasowy (bez zwrotu } \\
\text { gotówki właścicielom); } \\
\text { dodatkowe środki wpły- } \\
\text { nęły w związku z nową } \\
\text { emisją akcji }\end{array}$ & $\begin{array}{l}\text { Niekorzystne: dotych- } \\
\text { czasowy właściciel } \\
\text { traci w wyniku obniżenia } \\
\text { wartości nominalnej jego } \\
\text { zasobu, bez zwrotu zaan- } \\
\text { gażowanych kwot oraz } \\
\text { w wyniku zmniejszenia } \\
\text { jego udziału w kapitale } \\
\text { i głosach }\end{array}$ \\
\hline $\begin{array}{l}\text { Korekta wartości } \\
\text { nominalnej do } \\
\text { poziomu war- } \\
\text { tości rynkowej } \\
\text { (kursu giełdowe- } \\
\text { go) oraz pozy- } \\
\text { skanie kapitału } \\
\text { na finansowanie } \\
\text { działalności }\end{array}$ & \begin{tabular}{|l|} 
Devora, Mosto- \\
stal Export, JHM \\
Development, \\
Index Coperni- \\
cus Internatio- \\
nal, BNP Paribas \\
Bank Polska, \\
Trion, Art New \\
Media, GPPI, \\
Fon Ecology
\end{tabular} & $\begin{array}{l}\text { Obniżenie war- } \\
\text { tości nominalnej } \\
\text { akcji i emisja } \\
\text { nowych akcji }\end{array}$ & $\begin{array}{l}\text { Korzystne: część kapitału } \\
\text { zakładowego została } \\
\text { przeksięgowana na kapitał } \\
\text { zapasowy (bez zwrotu } \\
\text { gotówki właścicielom); } \\
\text { dodatkowe środki wpły- } \\
\text { nęły w związku z nową } \\
\text { emisją akcji }\end{array}$ & $\begin{array}{l}\text { Niekorzystne: dotych- } \\
\text { czasowy właściciel } \\
\text { traci w wyniku obniżenia } \\
\text { wartości nominalnej jego } \\
\text { zasobu, bez zwrotu zaan- } \\
\text { gażowanych kwot oraz } \\
\text { w wyniku zmniejszenia } \\
\text { jego udziału w kapitale } \\
\text { i głosach }\end{array}$ \\
\hline
\end{tabular}

Źródło: opracowanie własne na podstawie analizy raportów bieżących.

Wszystkie analizowane podmioty osiągnęły założone cele, tj. dokonały zmiany struktury własnościowej, zmiany alokacji aktywów, pokrycia strat, pozyskania dodatkowych środków. Zastosowane rozwiązania przyniosły jednak zróżnicowane skutki dla sytuacji majątkowej i kapitałowej spółki oraz pozycji dotychczasowych akcjonariuszy. W żadnej ze spółek celem nie było zwiększenie czy zmniejszenie zakresu działania.

Warto zwrócić uwagę, że tymi samymi metodami można osiągać różne cele generujące różne skutki zarówno dla spółki, jak i dla właścicieli. W odmienny sposób, w zależności od sytuacji, następuje zmiana struktury kapitału (w relacji kapitału własnego i kapitału obcego), ale też struktury kapitału własnego (w relacji kapitał zakładowy i kapitał zapasowy), w różny sposób zmienia się także wartość majątku (gotówki oraz aktywów trwałych). Różne sytuacje generują odmienne konsekwencje dla właścicieli w kontekście posiadanego ich zasobu majątkowego (wartość posiadanego zasobu akcji i/lub gotówki) oraz możliwości oddziaływania na sprawy spółki (udział w kapitale i liczbie głosów).

\section{Zakończenie}

Wbrew pozornej sprzeczności w procesie jednoczesnego obniżenia i podwyższenia kapitału zakładowego działania tego rodzaju są podejmowane w praktyce i posiadają ekonomiczne uzasadnienie. Jednoczesne obniżenie i podwyższenie kapitału zakładowego może być inicjowane zarówno przez właścicieli, jak i spółkę. Zróżnicowanie przesłanek przekłada się na możliwość stosowania różnych metod obniżenia i podwyższenia kapitału zakładowego, generując odmienne konsekwencje 
dla spółki (w zakresie struktury kapitału i majątku) oraz dla właścicieli (w zakresie wartości posiadanego zasobu akcji i udziału w kapitale).

W praktyce najczęściej stosowane metody to obniżenie wartości nominalnej akcji i emisja nowych akcji oraz umorzenie akcji i emisja nowych akcji. Metody te pozwalają osiągnąć wiele różnych celów, począwszy od strategii spółki dominującej w zakresie rozdysponowania zasobów między spółki wchodzące w skład grupy kapitałowej, przez zmiany w strukturze własności zachodzące bądź to z inicjatywy właścicieli, bądź spółki, aż do poprawy sytuacji spółki nawet kosztem sytuacji majątkowej i pozycji dotychczasowych właścicieli.

Wszystko to powoduje, że jednoczesne obniżenie i podwyższenie kapitału zakładowego stanowi elastyczny instrument, który może być wykorzystywany w szczególnych momentach w funkcjonowaniu spółki. Ze względu na istotne zmiany w substancji majątkowej i kapitałowej spółki oraz właścicieli wymagana jest jednak decyzja walnego zgromadzenia.

\section{Bibliografia}

Chojnacka E., Struktura kapitału spółek akcyjnych w Polsce w świetle teorii hierarchii źródel finansowania, CeDeWu, Warszawa 2012.

Duliniec A., Finansowanie przedsiębiorstwa. Strategie i instrumenty, PWE, Warszawa 2011.

Grzywacz J., Kapitał w przedsiębiorstwie i jego struktura, Wydawnictwo SGH, Warszawa 2008.

Ickiewicz J., Pozyskiwanie i struktura kapitału a dtugookresowe cele przedsiębiorstwa, Wydawnictwo SGH, Warszawa 2011.

Kosiorkiewicz M., Podwyższanie kapitału akcyjnego w publicznych spółkach akcyjnych, Dom Wydawniczy Ostoja, Kraków 1999.

Ostaszewski J., Cicirko T., Finanse spółki akcyjnej, Difin, Warszawa 2005.

Sajnóg A., Funkcje i cele podwyższania kapitału zakładowego, „Acta Universitatis Lodziensis. Folia Oeconomica" 2013, nr 278.

Skawiańczyk K., Podwyższenie kapitału zakładowego w spółce z ograniczoną odpowiedzialnością, Wolters Kluwer, Warszawa 2009.

Ustawa z dnia 15 września 2000 r. - Kodeks spółek handlowych (t.j. Dz. U. 2013, poz. 1030 z późn. zm.). Waśniewski T., Analiza finansowa w przedsiębiorstwie, FRRwP, Warszawa 1997.

Woźniak-Sobczak B., Funkcje kapitału w strategicznym zarządzaniu przedsiębiorstwem, Wydawnictwo Akademii Ekonomicznej w Katowicach, Katowice 2005.

\section{Simultaneous Decrease and Increase of the Share Capital - Reasons and Results}

Share capital is the basis of corporation. It can be increased in the time of development and decreased in the time of activity contracting. But the simultaneous decrease and increase of the share capital serves different aims and allows to meet different needs. The aim of this paper is to identify the reasons and the results of simultaneous decrease and increase of the share capital. The sample contains 20 companies. The analysis covers the period 2010-2014. The most common ways of simultaneous decrease and increase of share capital are the following: a) the decrease in the face value of the share and issuance new shares and $b$ ) redemption of shares and issuance new shares. These ways allow to allocate the resources among 
the companies in the capital group, allow to change the ownership structure initiated by both owners and company, and allow to improve the financial standing of the company at the expense of the shareholders. Because the simultaneous decrease and increase of the share capital includes different results for the company (capital structure and the pool of assets) and for the shareholders (the pool of shares and the stake in the company), it is a flexible tool of achieving aims at the specific moments of running the corporation.

\section{Jednoczesne obniżenie i podwyższenie kapitału zakładowego - przyczyny i skutki}

Kapitał zakładowy jest elementem kapitałów własnych przedsiębiorstwa. Odgrywa on istotną rolę w finansowaniu majątku oraz wypełnia szereg innych funkcji mających znaczenie zarówno dla samego przedsiębiorstwa, jak i dla współpracujących z nim podmiotów oraz właścicieli. W literaturze przedmiotu powszechnie przyjmuje się, że kapitał zakładowy powinien być podwyższany w sytuacji intensywnego wzrostu przedsiębiorstwa, natomiast obniżany w sytuacji, gdy przedsiębiorstwo ogranicza swój zakres działania i majątku. Zaobserwowane przypadki jednoczesnego obniżenia i podwyższenia kapitału zakładowego nie mieszczą się jednak w tak ujętych potrzebach zmiany poziomu kapitału zakładowego. Jednoczesne obniżenie i podwyższenie kapitału wydaje się być nieuzasadnione z ekonomicznego punktu widzenia, szczególnie gdy kapitał jest obniżany i podwyższany o taką samą kwotę, a dodatkowo należy ponieść koszty przeprowadzenia procedury obniżenia i podwyższenia kapitału.

Autorka niniejszego opracowania dostrzegła problem badawczy, który można określić jako identyfikację przyczyn oraz skutków jednoczesnego zastosowania obniżenia i podwyższenia kapitału zakładowego. Dla tak określonego celu została sformułowana hipoteza badawcza stwierdzająca, że jednoczesne obniżenie i podwyższenie kapitału zakładowego jest narzędziem realizowanych przez podmioty gospodarcze działań innych niż związane ze zwiększaniem czy zmniejszaniem zakresu działania. Dla potrzeb weryfikacji postawionej hipotezy zastosowano metodę analizy przypadków w latach 2010-2014. W okresie tym zidentyfikowano 20 przypadków jednoczesnego podwyższenia i obniżenia kapitału zakładowego. 